\title{
PENGARUH PENERAPAN STRATEGI PEMBELAJARAN THINK PAIR SHARE (TPS) TERHADAP KETERAMPILAN METAKOGNITIF, KEMAMPUAN BERPIKIR, DAN PEMAHAMAN KONSEP SISWA KELAS VII SMP NEGERI 1 PUJON DENGAN KEMAMPUAN AKADEMIK YANG BERBEDA
}

\author{
Rudi Yulianto \\ Jurusan Pendidikan Biologi FMIPA Universitas Negeri Malang
}

\begin{abstract}
ABSTRAK
Kegiatan belajar di sekolah dirancang untuk mencapai tujuan pembelajaran. Aspek yang harus dikembangkan dalam diri siswa yakni kemampuan berpikir dan keterampilan metakognitif. Diupayakan guru dapat dengan baik memberdayakan siswa berkemampuan akademik rendah sehingga memiliki hasil belajar yang sejajar dengan siswa berkemampuan akademik tinggi.

Penelitian ini dilakukan di SMP Negeri 1 Pujon selama semester gasal 2007/2008. Populasi dalam penelitian ini adalah seluruh siswa SMP Negeri 1 Pujon Kelas VII tahun ajaran 2007/2008. Sampel dalam penelitian ini adalah siswa kelas VII A sebagai kelas kontrol dan siswa kelas VII E sebagai kelas eksperimen. Siswa kelas VIIA terdiri atas 32 orang sedangkan siswa kelas VII E terdiri dari 35 orang. Rancangan penelitian ini adalah rancangan penelitian eksperimen semu dengan desain penelitian control group pre test post test.

Berdasarkan hasil penelitian yang telah diperoleh, terlihat bahwa strategi pembelajaran TPS dapat diandalkan dalam rangka meningkatkan keterampilan metakognitif, kemampuan berpikir, dan pemahaman konsep. Melihat fakta yang telah ditunjukkan, maka diharapkan guru dapat menerapkan penggunaan strategi pembelajaran TPS dalam kegiatan pembelajaran di sekolah. Selain itu pada penelitian ini strategi pembelajaran yang dipakai adalah strategi pembelajaran TPS, maka dapat dicobakan strategi pembelajaran lain untuk mengetahui pengaruhnya terhadap keterampilan metakogitif, kemampuan berpikir, dan pemahaman konsep siswa pada siswa dengan kemampuan akademik yang berbeda.
\end{abstract}

Kata kunci: TPS, keterampilan metakognitif, kemampuan berpikir, pemahaman konsep, kemampuan akademik

\section{PENDAHULUAN}

Belajar merupakan aktivitas yang dialami oleh manusia sepanjang hayatnya. Ciri-ciri kegiatan belajar itu sendiri menurut Morgan (dalam Syah 1995) meliputi perubahan tingkah laku yang perubahan tersebut terjadi karena latihan dan pengalaman bukan karena pertumbuhan. Perubahan tersebut harus bersifat permanen dan tetap ada untuk waktu yang cukup lama.Kegiatan pembelajaran yang ideal adalah kegiatan belajar yang dalam pelaksanaannya selalu melibatkan siswa secara aktif. Rahmat (2008) pada pembelajaran yang ideal guru tidak lagi mendominasi pembelajaran, siswa sebagai subjek pembelajaran, guru kreatif dan inovatif dalam merencanakan pembelajaran, pembelajaran berorientasi kepada kehidupan nyata tidak hanya kepada buku.

Faktor yang dapat mempengaruhi tercapainya tujuan belajar yang berasal dari diri siswa antara lain adalah kemampuan berpikir siswa. Dalam
Corebima (2005a) disebutkan bahwa ada banyak kajian yang menemukan bahwa ada hubungan (bahkan pengaruh) antara kemampuan penalaran formal dan prestasi belajar biologi. Kegiatan berpikir memiliki peran yang sangat penting artinya bagi pemahaman konsep siswa. Eggen dan Kauchak (1996) dalam Corebima (2005a) tanpa penekanan terhadap berpikir, pemahaman mendalam akan isi pembelajaran sesungguhnya tidak mungkin. Dari pernyataan-pernyataan ini tampak dengan jelas pentingnya kemampuan berpikir dalam kegiatan pembelajaran. Untuk itu berbagai upaya yang ditujukan untuk meningkatkan kemampuan berpikir perlu diusahakan.

Kemampuan berpikir yang baik dapat dikembangkan melalui kegiatankegiatan atau pengalaman yang dapat mendorong peningkatan kemampuan berpikir. Pada kegiatan pembelajaran di sekolah upaya peningkatan kemampuan berpikir ini dapat dilakukan melalui 
berbagai teknik. Menurut Marzano (1993, dalam Corebima 2005a) ada tiga upaya utama yang dapat dilakukan untuk meningkatkan kemampuan berpikir siswa. Ketiga upaya tersebut adalah teknik bertanya, teknik menulis, dan strategi pemrosesan informasi umum. Ketiga macam upaya ini dapat dilakukan secara terpisah dalam rangka meningkatkan kemampuan berpikir siswa.

Selain kemampuan berpikir yang baik, keterampilan metakognitif siswajugadapat membantu peningkatan pemahaman konsep siswa. Arends (1998, dalam Corebima 2006) pengertian metakognitif adalah proses mengetahui dan memonitor proses berpikir atau proses kognitif sendiri. Keterampilan metakognitif memiliki arti penting dalam proses pembelajaran. Eggen dan Kauchak (1996, dalam Corebima 2006) menyatakan bahwa pengembangan kecakapan metakognitif pada para siswa adalah suatu tujuan pendidikan yang berharga, karena kecakapan itu dapat membantu mereka menjadi self regulated learners. Self regulated learner bertanggung jawab terhadap kemajuan belajarnya sendiri dan mengadaptasi strategi belajarnya mencapai tuntutan tugas. Dengan demikian siswa akan dapat mencapai semua tujuan dengan baik karena siswa dapat memonitor sendiri kekurangan-kekurangan yang dimilikinya sehingga memungkinkan untuk diadakannya perbaikan dalam diri siswa oleh siswa sendiri karena siswa mengetahui secara jelas kekurangan yang dimilikinya.

Di dalam suatu kelas yang baik terdapat siswa dengan kemampuan akademik yang heterogen, yakni siswa dengan kemampuan awal yang berbedabeda. Winarni (2006, dalam Habibah, 2008) menyatakan bahwa kemampuan akademik adalah gambaran tingkat pengetahuan atau kemampuan siswa terhadap suatu materi pelajaran yang sudah dipelajari dan dapat digunakan sebagai bekal atau modal untuk memperoleh pengetahuan yang lebih luas dan kompleks lagi. Kondisi kelas yang heterogen dalam hal kemampuan akademik ini diperlukan agar setiap siswa memiliki kesempatan belajar yang sama di dalam kelas. Diharapkan siswa dengan kemampuan akademik rendah dapat mencapai hasil yang setara dengan siswa berkemampuan akademik tinggi untuk mencapai tujuan pembelajaran.

Kenyataan di lapangan menunjukkan hal yang berbeda dengan pembelajaran yang ideal yang seharusnya dijalankan oleh seorang guru. Salah satu sekolah yang belum menghadirkan pembelajaran yang ideal di sekolah adalah SMP Negeri 1 Pujon. Berdasarkan hasil observasi dengan cara wawancara dengan guru mata pelajaran biologi di SMP Negeri 1 Pujon, didapatkan keterangan bahwa pengajaran biologi di sekolah tersebut masih menggunakan strategi yang bertipe teacher centered. Kondisi siswa dalam kelas memang sudah heterogen yakni terdapat siswa berkemampuan akademik rendah maupun tinggi, namun dengan tipe pembelajaran teacher centered perbedaan ini akan terabaikan sehingga besar kemungkinan siswa berkemampuan akademik rendah tidak mampu mengembangkan dirinya untuk mencapai prestasi belajar yang setara dengan siswa berkemampuan akademik tinggi. Dalam pelaksanaan kegiatan belajar dengan tipe ini kebanyakan kegiatan pembelajaran berupa ceramah. Dari sini dapat dilihat bahwa keterlibatan siswa dalam kegiatan pembelajaran masih belum optimal. Siswa memiliki sedikit kesempatan untuk bekerjasama dengan siswa lain atau dengan kata lain aktivitas sosial dalam kegiatan belajar antara siswa berkemampuan akademik tinggi dan rendah sangat kecil kemungkinannya, padahal interaksi antara siswa berkemampuan akademik tinggi dan rendah diperlukan untuk membantu memberdayakan siswa berkemampuan akademik rendah. Kondisi seperti ini 
dapat diperbaiki dengan penggunaan strategi-strategi pembelajaran kooperatif yang mampu meningkatkan keterlibatan siswa dalam proses kegiatan belajar.

Strategi-strategi pembelajaran yang sering dipakai dalam upaya peningkatan keterlibatan siswa antara lain adalah strategi pembelajaran kooperatif. Selain meningkatkan keterlibatan siswa secara aktif strategi-strategi pembelajaran kooperatif juga mampu meningkatkan kemampuan berpikir siswa. Susilo (2005) menyebutkan berbagai macam strategi pembelajaran kooperatif, Think Pair Share (TPS), Jigsaw II, Student Team Learning (STL), Student Team Achievement Division (STAD), dan Teams-Games-Tournament (TGT).

Di antara strategi-strategi yang telah disebutkan di atas yang sudah sering dipakai adalah strategi pembelajaran Think Pair Share (TPS). Menurut Susilo (2005), strategi ini merupakan strategi yang belum disebut Slavin (1995) sebagai yang banyak diteliti saat itu tapi sepuluh tahun setelah itu kondisinya sudah berbeda. Susilo (2005) menyebutkan bahwa strategi pembelajaran TPS merupakan suatu strategi yang dikembangkan oleh Frank Lyman dan kawan-kawannya di Universitas Maryland pada tahun 1981. Strategi ini memperkenalkan ide waktu berpikir atau waktu tunggu yang menjadi faktor kuat dalam meningkatkan kemampuan siswa merespons pertanyaan.

Strategi pembelajaran TPS sering digunakan karena memiliki beberapa alasan. Dalam www.uteyar.edu/academic/cite/howleft/str ucture.html dalam Susilo (2005) termuat alasan-alasan dipakainya strategi pembelajaran TPS yakni strategi TPS dapat membantu menstrukturkan diskusi, meningkatkan partisipasi siswa dan banyaknya informasi yang dapat diperoleh siswa, meningkatkan lama waktu time on task dalam kelas dan kualitas kontribusi siswa, dan siswa dapat mengembangkan kecakapan hidup sosial mereka. Strategi TPS dapat membuat siswa dapat berpikir lebih terarah dan dapat meningkatkan aktivitas siswa dalam kegiatan belajar karena siswa dituntut melaporkan hasil berpikirnya pada temantemannya. Pada strategi ini siswa dituntut untuk dapat bekerja secara bersama-sama dengan teman sebayanya. Kegiatan ini dapat meningkatkan kegiatan sosial siswa. Dengan demikian strategi ini diharapkan dapat meningkatkan kemampuan berpikir siswa.

Strategi pembelajaran kooperatif Think Pair Share (TPS) selain dapat meningkatkan keterterlibatan siswa dalam kegiatan belajar, aktivitas berpikir siswa juga dapat ditingkatkan. Melalui strategi ini siswa diharapakan mampu berpikir sendiri dan memberikan laporan kepada siswa lain mengenai hasil proses berpikirnya. Dengan demikian kegiatan berpikir menjadi lebih terarah karena ada tuntutan untuk melaporkan hasil berpikirnya kepada teman-temannya. Sehingga dapat diharapakan bahwa pemahaman konsep siswa juga akan lebih baik karena siswa dapat berperan aktif dalam kegiatan belajarnya.

Berdasarkan latar belakang di atas, maka penulis mengadakan penelitian dengan judul Pengaruh Penerapan Strategi Pembelajaran Think Pair Share (TPS) terhadap Keterampilan Metakognitif, Kemampuan Berpikir, dan Pemahaman Konsep Siswa Kelas VII SMPN I Pujon dengan Kemampuan Akademik yang Berbeda.

\section{METODE PENELITIAN}

Rancangan penelitian ini menggunakan rancangan penelitian eksperimen semu. Pada penelitian ini digunakan kelompok kontrol dan kelompok eksperimen yang kedua-duanya terbentuk secara wajar (alamiah) sejak awal. Desain penelitian yang digunakan adalah control group pre test post test.Populasi dalam penelitian ini adalah seluruh siswa kelas VII SMPN 1 Pujon tahun ajaran 2007/2008. Sampel penelitian 
adalah siswa kelas VII A dan VII E. Kelas VII A merupakan kelas yang dipakai sebagai kelas kontrol sementara kelas VII E dipakai sebagai kelas eksperimen. Penentuan kelas yang dipakai untuk diteliti dilakukan secara acak yaitu pada kelas-kelas yang memiliki siswa dengan kemampuan akademik yang heterogen. Berkaitan dengan jumlah, kelas VII A berjumlah 32 siswa dan kelas VII E berjumlah 35 orang.

\section{HASIL DAN PEMBAHASAN}

\section{A. Pengaruh Penerapan Strategi Pembelajaran Think Pair Share (TPS) terhadap Keterampilan Metakognitif pada Siswa dengan Kemampuan Akademik yang Berbeda.}

Hasil penghitungan uji Anava didapatkan kesimpulan sebagai berikut.

a. Nilai probabilitas strategi pembelajaran 0,003 atau kurang dari 0,05 sehingga hipotesis nol ditolak dan hipotesis penelitian diterima. Artinya strategi pembelajaran berpengaruh terhadap keterampilan metakognitif siswa. Setelah dilakukan pembandingan reratanya terlihat bahawa rerata kelas eksperimen sebesar 54,91 sedangkan rerata siswa pada kelas kontrol sebesar 44,60. berdasarkan perbandingan tersebut maka dapat dilihat bahwa hasil yang didapatkan menunjukkan bahwa strategi pembelajaran TPS dapat meningkatkan keterampilan metakognitif siswa lebih tinggi dan berbeda nyata dengan strategi pembelajaran konvensional.

b. Nilai probabilitas kemampuan akademik 0,057 atau lebih dari 0,05 sehingga hipotesis nol diterima dan hipotesis penelitian ditolak. Artinya kemampuan akademik tidak berpengaruh terhadap keterampilan metakognitif siswa. Meskipun demikian tampaknya siswa dengan kemampuan akademik tinggi memiliki nilai keterampilan metakognitif yang lebih tinggi dari pada siswa berkemampuan akademik rendah meskipun perbedaan ini tidak signifikan. Adanya perbedaan ini dapat dilihat dari perbedaan mean antara siswa berkemampuan akademik tinggi dan rendah. Siswa berkemampuan akademik tinggi memiliki mean sebesar 53,1 sedangkan siswa berkemampuan akademik rendah memiliki nilai mean sebesar 46,9.

c. Nilai probabilitas interaksi antara strategi pembelajaran dan kemampuan akademik 0,378 atau lebih besar dari 0,05 sehingga hipotesis nol diterima dan hipotesis penelitian ditolak. Artinya interaksi antara strategi pembelajaran dan kemampuan akademik tidak berpengaruh secara signifikan terhadap keterampilan metakognitif siswa. Setelah dilakukan uji lanjut LSD tampaknya ada perbedaan antara tiaptiap taraf interaksi. Strategi TPS berinteraksi dengan kemampuan akademik tinggi tampaknya memberikan hasil paling tinggi yang tidak berbeda nyata dengan taraf strategi TPS pada siswa berkemampuan akademik rendah, namun berbeda nyata dengan taraf interaksi antara strategi pembelajaran konvensional pada siswa berkemampuan akademik tinggi dan strategi konvensional pada siswa berkemampuan akademik rendah.

Pengaruh penerapan strategi pembelajaran TPS terhadap kemampuan metakognitif siswa dilihat menggunakan dua cara. Cara yang pertama yakni dengan menggunakan inventori metakognitif dan cara yang kedua yakni dengan menggunakan hasil pre tes dan post tes.

Adanya fakta yang menunjukkan bahwa dengan menggunakan dua instrumen yang berbeda menghasilkan kesimpulan yang sama membuktikan kesejajaran kedua instrumen. Instrumen inventori metakognitif dapat menunjukkan kenyataan yang sama dengan yang ditunjukkan oleh hasil pre tes dan post tes. 
Pada penelitian ini, untuk melihat keterampilan metakognitif dipakai dengan dua cara karena keterampilan metakognitif dapat dilihat dengan kedua cara tersebut. Habibah (2006) keterampilan metakognitif dapat juga dilihat dengan menggunakan hasil pra tes dan post tes siswa selain dengan menggunakan inventori metakognitif.

Kedua instrumen memang dapat mengungkap hal yang persis sama namun pada kenyataan di lapangan, penggunaan inventori tampaknya tidak selalu efektif meskipun inventori ini telah diuji validitasnya. Banyak terjadi hal-hal yang tidak diharapakan di lapangan. Pada saat mengisi inventori kadang siswa terkesan asal dan tergesagesa dalam mengerjakan. Hal tersebut terlihat dari 52 butir pernyataan yang harus ditanggapi, semuaya dapat terjawab dalam kurun waktu yang sangat singkat. Bahkan dalam 15 menit ada siswa yang sudah selesai mengerjakan inventori tersebut. Instrumen pre tes dan post tes memliki kelebihan yang tidak dimiliki oleh inventori metakognitif. Saat mengerjakan tes siswa mengerjakan dengan konsentrasi sepenuhnya sehingga hasil yang diperoleh benarbenar menunjukkan kondisi siswa. Berbagai fakta yang telah terungkap mengenai instrumen-instrumen tersebut dapat dipahami bahwa kedua instrumen dapat dipakai untuk melihat keterampilan metakognitif siswa karena hasil yang diperoleh nantinya akan sama.

Berdasarkan kesimpulan yang telah diperoleh dari data yang telah dikumpulkan dengan dua cara yaitu dengan menggunakan tes maupun dengan menggunakan inventori, tampaknya strategi pembelajaran TPS terbukti lebih mampu meningkatkan keterampilan metakognitif siswa dari pada strategi pembelajaran konvensional.

Keterampilan metakognitif siswa dipengaruhi oleh strategi pembelajaran yang digunakan, dalam hal ini tipe pembelajaran kooperatif TPS. Pembelajaran dengan strategi TPS dapat meningkatkan keterampilan metakognitif siswa karena pada strategi pembelajaran ini diperlukan interaksi sosial antar siswa dalam kelas.

Slavin (dalam Yasa, 2008)

pembelajaran kooperatif adalah

pembelajaran yang dilakukan secara berkelompok, siswa dalam satu kelas dijadikan kelompok-kelompok kecil yang terdiri dari 4 sampai 5 orang untuk memahami konsep yang difasilitasi oleh guru. Dalam pembelajaran kooperatif ini pembelajaran dilaksanakan dengan setting kelompok-kelompok kecil dengan memperhatikan keberagaman anggota kelompok sebagai wadah siswa bekerjasama dan memecahkan suatu masalah melalui interaksi sosial dengan teman sebayanya, memberikan kesempatan pada peserta didik untuk mempelajari sesuatu dengan baik pada waktu yang bersamaan dan ia menjadi narasumber bagi teman yang lain. Pembelajaran kooperatif mendorong terjadinya interaksi sosial. Interaksi sosial yang terjadi ketika dilakukan pembalajaran dengan strategi pembelajaran kooperatif inilah yang mampu meningkatkan keterampilan metakognitif siswa. Middlefedt dan Grotzer (2003 dalam Habibah 2008) perkembangan metakognitif tidak terjadi melalui kekosongan (vakum) sosial.

Strategi pembelajaran TPS memiliki sintaks berupa Think Pair Share. Sintaks TPS yang seperti ini memberikan kesempatan yang lebih besar pada siswa untuk memonitor dirinya sendiri dan merancang pemikiran yang harus disampaikan kepada rekan kerjanya. Jones (2002) dalam Susilo (2005) proses berpikir individual pada tahap Think dapat terstruktur karena mengikuti proses tertentu sehingga membatasi kesempatan pikirannya melantur karena mereka harus berpikir yang nantinya hasil pemikiran ini akan dilaporkan ke mitranya atau teman 
pasangannya. Jadi pada tahap Think siswa telah dituntut untuk merancang hasil pemikiran yang akan dilaporkan kepada teman sebayanya, sehingga siswa sadar pada kemampuan kognitif dirinya sendiri. Menurut Eggen dan Kauchak (1996, dalam Corebima 2006) metakognitif berarti kesadaran dan kontrol terhadap proses kognitif.

Keterampilan metakognitif pada siswa dengan kemampuan akademik yang berbeda tidak berbeda nyata, begitu juga dengan interaksi antara strategi dengan kemampuan akademik. Hal ini ditunjukkan dari hasil penghitungan statistik yang menunjukkan nilai probabilitas untuk kemampuan akademik dan interaksi antara strategi dengan kemampuan akademik yang lebih dari 0,05 . artinya baik siswa berkemampuan akademik tinggi maupun rendah memiliki keterampilan metakognitif yang sama.

Menurut Thompson, et al. (1995, dalam Yusuf 2003) pembelajaran kooperatif turut menambah unsur-unsur interaksi sosial pada pembelajaran sains. Di dalam pembelajaran kooperatif siswa belajar bersama dalam kelompokkelompok kecil yang saling membantu satu sama lain. Dengan adanya kegiatan saling membantu ini dapat dipahami terjadi interaksi antara siswa dengan kemampuan akademik yang berbeda. Akibat dari interaksi ini siswa dengan kemampuan akademik rendah akan tertolong dan mampu meningkatkan hasil belajarnya karena belajar dari siswa dengan kemampuan akademik yang lebih tinggi. Pembelajaran kooperatif memiliki dampak yang cukup positif bagi siswa yang hasil belajarnya rendah sehingga mampu mampu meningkatkan hasil belajarnya secara signifikan (Yasa, 2008).

Berdasarkan penjelasan di atas maka dapat dimengerti bahwa strategi pembelajaran TPS mampu meningkatkan keterampilan metakognitif pada semua siswa, baik siswa berkemampuan akademik tinggi maupun siswa dengan kemampuan akademik rendah. Kenyataan ini ditunjukkan oleh fakta hanya strategi pembelajaran saja yang menunjukkan pengaruhnya terhadap keterampilan metakognitif siswa. Siswa dengan strategi pembelajaran TPS memiliki keterampilan metakognitif yang lebih tinggi dari siswa yang diajar dengan strategi pembelajaran konvensional.

\section{B. Pengaruh Penerapan Strategi Pembelajaran Think Pair Share (TPS) terhadap Kemampuan Berpikir pada Siswa dengan Kemampuan Akademik yang Berbeda. \\ Berdasarkan tabel ringkasan} Anakova diperoleh kesimpulan sebagai berikut.

a. Nilai probabilitas strategi pembelajaran 0,001 atau kurang dari 0,05 sehingga hipotesis nol ditolak dan hipotesis penelitian diterima. Artinya perbedaan strategi pembelajaran berpengaruh terhadap kemampuan berpikir siswa. Berdasarkan hasil perbandingan mean terkoreksi diperoleh kesimpulan bahwa strategi pembelajaran TPS memberikan pengaruh secara signifikan lebih tinggi dari pada strategi pembelajaran konvensional. Artinya kemampuan berpikir siswa dengan penerapan strategi pembelajaran TPS lebih tinggi dan berbeda nyata dengan kemampuan berpikir siswa yang diberi perlakuan strategi pembelajaran konvensional.

b. Nilai probabiltas kemampuan akademik 0,081 atau lebih dari 0,05 sehingga hipotesis nol diterima dan hipotesis penelitian ditolak. Artinya perbedaan kemampuan akademik siswa tidak berpengaruh terhadap kemampuan berpikir siswa. Namun meskipun demikian, ada kecenderungan bahwa siswa dengan kemampuan akademik tinggi memiliki kemampuan berpikir yang lebih tinggi daripada siswa dengan kemampuan akademik rendah. Hal ini terlihat dari hasil perbandingan mean terkoreksi yang telah dihitung. Nilai mean terkoreksi dari siswa 
berkemampuan akademik tinggi sebesar 43,08 sedangkan siswa berkemampuan akademik rendah sebesar 35,36. Berdasarkan hasil ini maka dapat diketahui kalau siswa dengan kemampuan akademik tinggi memiliki nilai yang lebih tinggi daripada siswa dengan kemampuan akademik rendah, meskipun perbedaan ini tidak terjadi secara signifikan.

c. Nilai probabilitas interaksi strategi dan kemampuan akademik adalah 0,781 atau lebih dari 0,05 sehingga hipotesis nol diterima dan hipotesis penelitian ditolak. Artinya interaksi antara strategi pembelajaran dengan kemampuan akademik tidak berpengaruh terhadap kemampuan berpikir siswa. Namun jika dilihat lebih lanjut dengan uji LSD tampak bahwa interaksi antara strategi pembelajaran TPS dengan kemampuan akademik tinggi memberikan hasil yang tertinggi berbeda nyata dengan siswa berkemampuan akademik rendah dengan strategi yang sama. Siswa berkemampuan akademik tinggi dengan strategi pembelajaran konvensional memiliki kemampuan berpikir yang berbeda dengan siswa berkemampuan akademik tinggi yang mendapat perlakuan pembelajaran TPS dan tidak berbeda dengan siswa berkemampuan akademik rendah yang mendapat perlakuan strategi pembelajaran konvensional.

Strategi TPS mampu meningkatkan kemampuan berpikir siswa karena pada strategi ini siswa diberikan kesempatan waktu untuk berpikir. Menurut Yuanita (2006) TPS merupakan salah satu metode pembelajaran kooperatif yang dapat membantu meningkatkan kemampuan penalaran siswa. TPS bertujuan meningkatkan penguasaan akademik. Pada strategi pembelajaran TPS siswa dituntut untuk berpikir sendiri dalam mengerjakan soal-soal yang ada pada lembar siswa yang dilakukan pada tahap Think. Selanjutnya siswa dituntut untuk berpikir bersama rekan belajaranya pada tahap Pair dan Share. Karena siswa selalu dituntut untuk berpikir maka dapat dipahami bahwa kemampuan berpikir siswa akan lebih meningkat.

Susilo (2005) strategi pembelajaran TPS membantu siswa untuk memusatkan pemikirannya pada pelajaran. Pada strategi pembelajaran ini seorang siswa dituntut untuk berpikir secara individu dan melaporkan hasil pemikirannya kepada pasangannya. Menurut Nurhadi; dkk (2004 dalam Yuanita 2005) strategi pembelajaran TPS mampu mengubah asumsi bahwa metode resitasi dan diskusi perlu diselenggarakan dalam setting belajar secara keseluruhan. Metode TPS memberikan kesempatan kepada siswa waktu untuk berpikir dan merespon serta saling bantu satu sam lain.

Strategi pembelajaran TPS merupakan salah satu dari berbagai macam strategi pembelajaran kooperatif. Pembelajaran kooperatif memiliki keuntungan berupa pengembangan kemampuan berpikir tingkat tinggi siswa. Cooper (dalam Yasa, 2008) mengungkapkan keuntungan dari metode pembelajaran kooperatif tersebut antara lain adalah sebagai berikut.

1. Siswa mempunyai tanggung jawab dan terlibat secara aktif dalam pembelajaran.

2. Siswa dapat mengembangkan keterampilan berpikir tingkat tinggi.

3. Meningkatkan ingatan siswa.

4. Meningkatkan kepuasan siswa terhadap materi pembelajaran.

Hasil penghitungan statistik menunjukkan kalau siswa dengan kemampuan akademik yang berbeda memiliki kemampuan berpikir yang tidak berbeda nyata. Namun setelah dilihat dari uji lanjut terlihat siswa dengan kemapuan akademik tinggi cenderung memiliki kemampuan berpikir yang lebih tinggi dari siswa berkemampuan akdemik rendah. Hal ini wajar terjadi karena siswa dengan kemampuan akademik yang berbeda bila diajar dengan pembelajaran yang sama akan menunjukkan hasil yang 
berbeda sesuai dengan kemampuan akademik awal mereka. Menurut Kusumastuti (2002, dalam Habibah, 2006) siswa yang pandai jika dibiasakan belajar dalam kondisi pembelajaran yang merencanakan pengelolaan secara sengaja ternyata dapat diketahui bahwa tingkat penalaran siswa pandai memang lebih tinggi daripada siswa kurang pandai.

$$
\text { Interaksi antara strategi }
$$

pembelajaran dan kemampuan akademik tidak berpengaruh pada kemampuan berpikir siswa. Setelah dilakukan uji lanjut ternyata siswa berkemampuan akademik tinngi yang diajar dengan strategi pembelajaran TPS memiliki kemampuan berpikir yang lebih tinggi dari siswa berkemampuan akademik rendah yang diajar dengan strategi yang sama. Namun tidak berbeda nyata dengan siswa berkemampuan akademik tinggi yang diajar dengan strategi pembelajaran konvensional. Siswa berkemampuan akademik rendah yang diajar dengan strategi pembelajaran konvensional memiliki kemampuan berpikir paling rendah namun tidak berbeda nyata dengan siswa berkemampuan akademik tinggi yang diajar dengan strategi pembelajaran yang sama.

Dari hasil kesimpulan di atas tampaknya strategi pembelajaran TPS mampu memberdayakan kemampuan berpikir siswa tingkat rendah sehingga mampu mencapai tingkat yang sama dengan siswa berkemampuan akademik tinggi yang diajar dengan metode konvensional. Fakta ini muncul karena pada strategi pembelajarn TPS siswa diharuskan untuk selalu berpikir setiap kali kegiatan pembelajaran dilaksanakan. Susilo (2005) menyatakan bahwa strategi pembelajaran TPS membantu siswa memusatkan pemikiran karena mereka harus berpikir secara individu dan melaporkan hasil pemikiranya pada pasangannya. Adanya perbedaan pada siswa berkemampuan tinggi yang diajar dengan strategi pembelajaran TPS karena siswa dengan kemampuan akademik tinggi memiliki kemampuan penalaran yang lebih baik. Corebima (2000) menyatakan bahwa bagi mereka yang tingkat penalarannya lebih tinggi, mampu menguji hipotesis keilmuan maupun mengidentifikasi variabel tergantung, serta lebih mampu menganalisis data.

\section{Pengaruh Penerapan Strategi Pembelajaran Think Pair Share (TPS) terhadap Pemahaman Konsep pada Siswa dengan Kemampuan Akademik yang Berbeda.}

Berdasarkan tabel ringkasan Anakova diperoleh kesimpulan seperti berikut ini.

a. Nilai probabilitas strategi sebesar 0,000 atau kurang dari 0,05 sehingga hipotesis nol ditolak dan hipotesis penelitian diterima. Artinya perbedaan strategi pembelajaran berpengaruh secara signifikan terhadap pemahaman konsep siswa. Berdasarkan perbandingan rerata terkoreksi tampak bahwa strategi pembelajaran TPS memberikan pengaruh lebih tinggi dan berbeda nyata dengan strategi pembelajaran konvensional. Nilai rerata terkoreksi siswa kelas eksperimen sebesar 43,52 sedangkan siswa kelas kontrol sebesar 33,97. Dari sini dapat dijelaskan bahwa strategi pembelajaran TPS telah terbukti dapat meningkatkan pemahaman konsep siswa lebih tinggi daripada strategi pembelajaran konvensional.

b. Nilai probabilitas kemampuan akademik sebesar 0,039 atau kurang dari 0,05 sehingga hipotesis nol ditolak dan hipotesis penelitian diterima. Artinya ada pengaruh kemampuan akademik terhadap pemahaman konsep siswa. Berdasarkan hasil perbandingan rerata terkoreksi tampak bahwa siswa dengan kemampuan akademik tinggi memiliki pemahaman konsep lebih tinggi dan berbeda nyata dengan siswa berkemampuan akademik rendah. Nilai rerata terkoreksi siswa kelas 
eksperimen adalah sebesar 41,51 sedangkan nilai rerata terkoreksi siswa kelas kontrol sebesar 35,99.

c. Nilai probabilitas interaksi strategi pembelajaran dengan kemampuan akademik sebesar 0,082 atau yang lebih dari 0,05 sehingga hipotesis nol diterima dan hipotesis penelitian ditolak. Artinya interaksi antara strategi pembelajaran dan kemampuan akademik tampaknya tidak memberikan pengaruh signifikan. Setelah dilakukan uji lanjut LSD tampak bahwa strategi pembelajaran TPS pada siswa berkemampuan akademik tinggi memberikan pengaruh paling besar dan berbeda dengan interaksi antara strategi pembelajaran TPS pada siswa dengan kemampuan akademik rendah. Di lain pihak interaksi antara strategi TPS dengan siswa berkemampuan akademik rendah ini tidak berbeda dengan siswa berkemampuan akademik tinggi dengan strategi pembelajaran konvensional namun berbeda dengan siswa berkemampuan akademik rendah yang diajar dengan menggunakan strategi pembelajaran konvensional.

Strategi pembelajaran TPS dapat meningkatkan pemahaman konsep siswa karena strategi ini memiliki tujuan untuk meningkatkan penguasaan akademik siswa. Menurut Yuanita dkk. (2005) TPS merupakan salah satu metode pembelajaran kooperatif yang dapat membantu meningkatkan kemampuan penalaran siswa. Metode TPS memberikan kesempatan kepada siswa waktu untuk berpikir dan merespon serta saling membantu satu sama lain. Dengan adanya kesempatan untuk memikirkan materi dan kesempatan berdiskusi memberikan kesempatan kepada siswa untuk dapat memahami materi secara lebih baik. Pada strategi pembelajaran TPS ini aspek kerja sama antar siswa dalam rangka memahami konsep juga ditingkatkan karena strategi TPS mencakup kegiatan diskusi dengan teman pasangan dan teman sekelas.
Pembelajaran kooperatif membawa siswa pada kondisi saling tergantung satu sama lain. Kondisi seperti ini akan mendorong siswa untuk dapat berperilaku sosial dengan lebih baik sehingga dapat mencapai tujuan pembelajaran. Selain itu pembelajaran kooperatif juga akan meningkatkan aktivitas berpikir siswa karena dituntut untuk dapat bekerja sama dengan teman sebayanya dalam penyelesaian permasalahan pada kegiatan pembelajaran.

Ibrahim dkk. (dalam Yasa, 2008) siswa yakin bahwa tujuan mereka akan tercapai jika dan hanya jika siswa lainnya juga mencapai tujuan tersebut. Untuk itu setiap anggota berkelompok bertanggung jawab atas keberhasilan kelompoknya. Siswa yang bekerja dalam situasi pembelajaran kooperatif didorong untuk bekerjasama pada suatu tugas bersama dan mereka harus mengkoordinasikan usahanya untuk menyelesaikan tugasnya. Dengan demikian jalannya kegiatan dalam kelas lebih terarah sehingga pemahaman konsep yang menjadi inti kegiatan pembelajaran di dalam kelas dapat tercapai dengan lebih mudah.

Pemahaman konsep siswa selain dipengaruhi oleh strategi pembelajaran juga dipengaruhi oleh kemampuan akademik siswa. Pada siswa dengan kemampuan akademik tinggi pemahaman konsep yang dimiliki lebih tinggi dari siswa dengan kemampuan akademik yang lebih rendah. Puspitasari (2006) ada hubungan antara kecakapan akademik (Academic Life Skill) dengan hasil belajar siswa pada pembelajaran Biologi dengan pola PBMP dan TPS. Semakain tinggi Academic Life Skill maka diikuti semakin tingginya hasil belajar siswa. Hal ini karena siswa dengan kemampuan akademik tinggi memiliki tingkat penalaran yang lebih tinggi daripada siswa dengan kemampuan akademik rendah. Corebima (2000) menyatakan bahwa siswa dengan tingkat penalaran yang lebih tinggi mampu menguji keilmuan maupun mengidentifikasi 
variabel serta lebih mampu menganalisis data. Berdasarkan pernyataan tersebut maka dapat dilihat bahwa siswa dengan kemampuan akademik lebih tinggi akan memiliki pemahamn konsep yang lebih baik dari pada siswa dengan kemampuan akademik rendah terkait dengan tingkatan penalaran yang berbeda pada kedua kelompok tersebut siswa.

Pemahaman konsep berkaitan erat dengan kemampuan berpikir siswa. Siswa dengan kemampuan berpikir lebih tinggi akan memiliki pemahaman konsep yang lebih baik dari pada siswa dengan kemampuan berpikir lebih rendah. Siswa dengan kemampuan berpikir yang lebih baik akan lebih mudah mencerna materi yang sedang diajarkan sehingga akan memperoleh pemahaman konsep yang lebih mendalam. Selain itu faktor keterampilan metakognitif juga turut berperan dalam pemahaman konsep. Siswa yang memiliki keterampilan metakognitif yang baik akan dapat memfokuskan perhatian pada aspek-aspek penting sehingga pemahaman terhadap konsep-konsep penting dapat dioptimalkan. Anonim (tanpa tahun) keterampilan metakognitif membantu untuk memfokuskan perhatian pada informasi penting dan menyimpan dalam ingatan yang terkadang pemfokusan perhatian ini dapat dilakukan melalui permodelan. Jadi keterampilan metakognitif berperan dalam upaya menyadarkan siswa mengenai bagianbagian penting yang harus dipahami dari suatu materi pelajaran.

\section{KESIMPULAN}

1. Penerapan strategi pembelajaran Think Pair Share berpengaruh terhadap keterampilan metakognitif pada siswa kelas VII SMPN I Pujon, sedangkan kemampuan akademik dan interaksi antara strategi pembelajaran dengan kemampuan akademik tidak berpengaruh.

2. Penerapan strategi pembelajaran Think Pair Share berpengaruh terhadap kemampuan berpikir pada siswa kelas VII SMPN I Pujon, sedangkan kemampuan akademik dan interaksi antara strategi pembelajaran dengan kemampuan akademik tidak berpengaruh.

3. Penerapan strategi pembelajaran Think Pair Share dan kemampuan akademik berpengaruh terhadap pemahaman konsep pada siswa kelas VII SMPN I Pujon sedangkan interaksinya tidak berpengaruh.

\section{DAFTAR PUSTAKA}

Anonim . Tanpa tahun. Metacognitive skills. http://education.calumet.purdue.edu/v ockell/EdPsyBook/Edpsy7/edpsy7_m eta.htm. [31 Mei 2008]

Akhda, M. Abdinal. 2008. Pengaruh Kemampuan Akademik Dan Keaktifan Berorganisasi Terhadap Profesionalisme Guru Di SMA Islam Al-Maarif Singosari.Malang: Skripsi tidak diterbitkan

Arikunto, Suharsimi. 2003. Dasar-Dasar Evaluasi Pendidikan Edisi Revisi. Cetakan 4. Jakarta: Bumi Aksara.

Corebima, A.D. 2006. Pengertian Metakognisi. Makalah pada pelatihan strategi metakognitif pada pembelajaran Biologi untuk guruguru Biologi SMA di kota Palangkaraya. 23 Agustus 2006.

Corebima, A.D. 2005a. Pengukuran Kemampuan Berpikir. Makalah padapelatihan PBMP (Pemberdayaan Berpikir Melalui Pertanyaan) pada pembelajaran dengan tema "Pemberdayaan Kemampuan Berpikir Selama Pembelajaran sebagai Langkah Strategis Implementasi Kurikulum 2004" bagi para guru dan mahasiswa sains biologi dalam rangka RUKK VA. 25 Juni 2005.

Corebima, A.D. 2005b. Pengembangan Model Pembelajaran IPA Biologi SMP Konstruktivis Kontekstual 
Berorientasi Life Skill dengan Pola PBMP (Pemberdayaan Berpikir Melalui Pertanyaan)di Kota dan kabupaten Malang. Laporan penelitian akhir tahun 2005.

Corebima, A.D. 2005c. Pemberdayaan Berpikir Siswa pada Pembelajarn Biologi: $\quad$ Suatu Penggalakan Penelitian Payung di Jurusan Biologi UM. Makalah disampaikan dalam seminar Nasional Biologi dan Pembelajarannya dengan Tema Menyiapkan Generasi Masa Depan melalui Pengembangan Biologi dan Pembelajarannya yang diselenggarakan oleh jurusan Biologi UM di Malang. 3 Desember 2005.

Fakhriati, Agus. 2007. Meningkatkan Pembelajaran Membaca BahasaInggris dengan Pendekatan Metakognitif. http://afakhriati.wordpress.com/2007/ 11/30/meningkatkan-pembelajaranmembaca-bi-dengan-pendekatanmetakognitif/ [31 Mei 2008]

Hadiningtyas, Anita W., Anggriani, Y., Corebima, A.D. Penerapan Pola Pemberdayaan Berpikir Melalui Pertanyaan (PBMP)Melalui Think Pair Share (TPS) Untuyk Meningkatkan Kemampuan Berpikir Pada Siswa SMP. Makalah disampaikan pada seminar nasional hasil PTK dan penelitian eksperimen dalam rangka RUKK VA tahun 2005 di Malang kerja sama anatar RUKK VA dan jurusan Biologi FMIPA UM. 3 Desember 2005

Habibah, Kurnia Nurul. 2008. Pengaruh Penerapan Strategi Pembelajaran TPS + PBMP terhadap Ketrampilan Metakognitif Kemampuan berpikir dan Pemahaman Konsep Siswa Kelas VII SMP Negeri 4 Malang. Malang: Skripsi tidak diterbitkan.

Moehnilabib, M, dkk. 2003. Dasar-dasar Metodologi Penelitian. Malang: LEMLIT Universitas Negeri Malang.

Mulyati, Yayuk. 2006. Penerapan Pemberdayaan Berpikir Melalui
Pertanyaan (PBMP) dengan Metode Think Pair Share pada Mata Pelajaran Sains untuk Meningkatkan Aktivitas dan Hasil Belajar Siswa Kelas IV Madrasah Ibtidaiyah Jenderal Sudirman Malang. Malang: Skripsi tidak diterbitkan.

Munawar, Imam. 2006. Metode Ketrampilan Metakognitif sebagai Upaya Meningkatkan Pemahaman Konsep Materi Dimensi 3 di SMA Laboratorium Universitas Negeri Malang Tahun Ajaran200/2006. Malang: Skripsi tidak diterbitkan.

Ningsih, Reni F. 2008. Penerapan Pembelajaran Kooperatif Model Think Pair Share (TPS) untuk Meningkatkan Kemampuan Berpikir dan Pemahamn Siswa pada Pembelajaran Biologi Kelas Xc SMAN Pasirian Lumajang. Malang: Skripsi tidak diterbitkan.

Purwanto, M. Ngalim. 1990. Strategi

Mengembangkan Kemampuan

Berpikir

Anak.http://amalia07.wordpress.com/ 2008/06/25/strategi-

mengembangkan-kemampuanberfikir-anak/ [31 mei 2008]

Puspitasari, Pitaloka. 2006. Hubungan Antara Acadenic Life Skill dan Hasil Belajar pada Pembelajaran Biologi dengan Pola Pemberdayaan Berpikir melalui Pertanyaan (PBMP) dan Metode Think Pair Share (TPS) Di Kelas 3-D SMP Negeri 1 Kepanjen Kabupaten Malang. Malang: Skripsi tidak diterbitkan.

Rahmat, Asep Zaenal. 2008. Strategi

Pembelajaran Berbasis TIK.

Pelatihan Pemanfaatan TIK Untuk

Pembelajaran Tingkat Nasional

Tahun 2008.

word=118.98.163.253/view.php?file= 28_Diklat_Master_Trainer/bahan/Mo dul+TIK+1 -

10/Modul+5/5+strategi+Pembelajara n. [22 desember 2008] 
Syah, Muhibbin. 1995. Psikologi

Pendidikan Suatu Pendekatan baru, Bandung, Remaja RosdaKarya.

http://www.smunet.com $/$ main.php? mode $=1 \&$ act $=$ pb $\&$ $\underline{\mathrm{xkd}=2}$ [26 april 2008]

Susilo, Herawati. 2005. Pembelajaran Kooperatif Think Pair Share. Makalah disajikan padapelatihan PBMP (Pemberdayaan Berpikir Melalui Pertanyaan) pada pembelajaran dengan tema "Pemberdayaan Kemampuan Berpikir Selama Pembelajaran sebagai Langkah Strategis Implementasi Kurikulum 2004" bagi para guru dan mahasiswa sains biologi dalam rangka RUKK VA. 25 Juni 2005.

Susilo, Herawati. 2003. Bahan Ajar Metode Penelitian Pendidikan. Malang: Jurusan Biologi Fakultas Matematika dan Ilmu Pengetahuan Alam Universitas Negeri Malang.

Yuanita, Anik R., K, Anna J., Corebima, A.D. Hubungan Antara Kemampuan Berpikir dan hasil Belajar pada Pembelajaran Biologi dengan Pola Pemberdayaan Berpikir Melalui Pertanyaan (PBMP) dan Think Pair Share (TPS) Siswa Kelas 3 SMP Negeri 18 Malang. Makalah padapelatihan PBMP (Pemberdayaan Berpikir Melalui Pertanyaan) pada pembelajaran dengan tema "Pemberdayaan Kemampuan Berpikir Selama Pembelajaran sebagai Langkah Strategis Implementasi Kurikulum 2004" bagi para guru dan mahasiswa sains biologi dalam rangka RUKK VA. 25 Juni 2006.

Yuanita, A.R. 2006. Hubungan Antara Kemampuan Berpikir dan hasil Belajar pada Pembelajaran Biologi dengan Pola Pemberdayaan Berpikir Melalui Pertanyaan (PBMP) dan Think Pair Share (TPS) di SMPN 18
Malang. Skripsi tidak diterbitkan. Malang: Universitas Negeri Malang Yusuf. 2005. Proses dan Hasil Belajar Biologi Melalui Pembelajaran Kooperatif (JIGSAW).http://www.damandiri.or.i d/file/yusufunsbab2.pdf[26 april 2008]

Yasa, Doantara. 2008. Metode Pembelajaran kooperatif. http://ipotes.wordpress.com/2008/05/ 10/metode-pembelajarankooperatif/[26 april 2008] 